\title{
Synthesis and Characterization of the $\mathbf{W}-$ Os Heterometallic Complex $\mathrm{Os}_{3}(\mathrm{CO})_{10}(\mu-\mathrm{H})\left(\mu-\eta^{3}-\mathrm{C}(=\mathrm{CHPh}) \mathrm{C} \equiv \mathrm{CW}(\mathrm{O})_{2}\left(\mathrm{C}_{5} \mathrm{Me}_{5}\right)\right):$ Evidence of Hydride Dislocation on a Triosmium Framework by Crystal Polymorphism
}

\author{
Te-Kun Huang, ${ }^{\dagger}$ Y un Chi ${ }^{*, \dagger}$ Shie-Ming Peng, ${ }^{*, \ddagger}$ and Gene-Hsiang Lee ${ }^{\ddagger}$ \\ Department of Chemistry, National Tsing Hua University, Hsinchu 30043, Taiwan, and \\ Department of Chemistry and Instrumentation Center, National Taiwan University, \\ Taipe 10764, Taiwan
}

Received November 30, 1998

\begin{abstract}
The heterometal lic compound $\mathrm{Os}_{3}(\mathrm{CO})_{10}(u-\mathrm{H})\left(u-\eta^{3}-\mathrm{C}(=\mathrm{CHPh}) \mathrm{C} \equiv \mathrm{CW}(\mathrm{O})_{2}\left(\mathrm{C}_{5} \mathrm{Me}_{5}\right)\right)(\mathbf{1})$, which possesses a bridging hydride and a $\mathrm{C} \equiv \mathrm{CC}=\mathrm{CHPh}$ ligand, is obtained on addition of the diynyl complex $\left(\mathrm{C}_{5} \mathrm{Me}_{5}\right) \mathrm{W}(\mathrm{O})_{2}(\mathrm{C} \equiv \mathrm{CC} \equiv \mathrm{CPh})$ to $\mathrm{Os}_{3}(\mu-\mathrm{H})_{2}(\mathrm{CO})_{10}$. ${ }^{1} \mathrm{H}$ NMR spectra show the occurrence of three isomers at equilibrium in solution, of which two isomers have been unambiguously characterized by an X-ray diffraction study. During subsequent tests of reactivity we isolated $\mathrm{Os}_{3}(\mathrm{CO})_{10}\left(\mu-\sigma: \eta^{2}-\mathrm{C} \equiv \mathrm{CCHCHPh}\right)(\mu-\mathrm{H})(2)$ and $\left(\mathrm{C}_{5} \mathrm{Me}_{5}\right) \mathrm{W}(\mu-\mathrm{O})_{2} \mathrm{Os}_{3}(\mathrm{CO})_{9}\left(u-\sigma: \eta^{2}-\mathrm{C} \equiv \mathrm{CCHCHPh}\right)$ (3) through two distinct processes initiated by removal of the $\left(\mathrm{C}_{5} \mathrm{Me}_{5}\right) \mathrm{W}(\mathrm{O})_{2}$ fragment and decarbonylation, respectively.
\end{abstract}

Examination of the bonding of ligated hydrocarbon moieties in metal cluster compounds provides detailed data that may be applicable to the characterization of chemisorbed intermediates on metal surfaces. ${ }^{1}$ While the chemistry of cluster complexes with small carbonrich ligands such as carbide, dicarbide, and alkynyl ligands has been investigated, ${ }^{2}$ it is only recently that the higher analogues of diynyl or polyynyl fragments have received similar attention as a result of the emerging synthetic application of materials possessing extended carbon unsaturation. ${ }^{3}$ This new trend is evident from several reports devoted to the syntheses and characterization of monometallic or dimetallic diynyl and polyynyl complexes. ${ }^{4}$

In seeking to extend these studies, the chemistry of diynylmetal complexes with organic substrates or with transition-metal clusters has been investigated. ${ }^{5}$ It is shown that the coupling occurred at the alkyne unit farther from the metal atom, displaying a reactivity

\footnotetext{
† National Tsing Hua University.

₹ National Taiwan University.

(1) (a) Thimmappa, B. H. S. Coord. Chem. Rev. 1995, 143, 1. (b) Zaera, F. Chem. Rev. 1995, 95, 2651.

(2) (a) J ohn, K. D.; Geib, S. J .; Hopkins, M. D. Organometallics 1996 15, 4357. (b) J ensen, M. P.; Phillips, D. A.; Sabat, M.; Shriver, D. F. Organometallics 1992, 11, 1859. (c) Norton, D. M.; Eveland, R. W.; Hutchison, J . C.; Stern, C.; Shriver, D. F. Organometallics 1996, 15, 3916. (d) Akita, M.; Moro-oka, Y. Bull. Chem. Soc. J pn. 1995, 68, 420 (e) Carty, A. J .; Hogarth, G.; Enright, G.; Frapper, G. Chem. Commun. 1997, 1883. (f) Doherty, S.; Corrigan, J . F.; Carty, A.J .; Sappa, E. Adv. Organomet. Chem. 1995, 37, 39. (g) J ensen, M. P.; Phillips, D. A.; Sabat, M.; Shriver, D. F. Organometallics 1992, 11, 1859. (h) Adams, C. J .; Bruce, M. I.; Skelton, B. W.; White, A. H. Chem. Commun. 1996, 975.

(3) (a) Blenkiron, P.; Taylor, N.J .; Carty, A. J .J . Chem. Soc., Chem. Commun. 1995, 327. (b) Bruce, M. I.; Ke, M.; Low, P. J. Chem. Commun. 1996, 2405. (c) Bruce, M. I.; Denisovich, L. I.; Low, P. J .; Peregudova, S. M.; Ustynyuk, N. A. Mendeleev Commun. 1996, 200 (d) Norton, D. M.; Stern, C. L.; Shriver, D. F.; J ensen, M. P.; Shriver, D. F. Inorg. Chem. 1994, 33, 2701. (e) Lang, H.; Weber, C. Organo-
} metallics 1995, 14, 4415. pattern influenced by steric effects. We report here a related coupling reaction of $\left(\mathrm{C}_{5} \mathrm{Me}_{5}\right) \mathrm{W}(\mathrm{O})_{2}(\mathrm{C} \equiv \mathrm{CC} \equiv \mathrm{CPh})$ with the dihydride complex $\mathrm{Os}_{3}(\mu-\mathrm{H})_{2}(\mathrm{CO})_{10}$, which proceeds smoothly to give the product $\mathrm{Os}_{3}(\mathrm{CO})_{10}(\mu-\mathrm{H})$ $\left(\mu-\eta^{3}-\mathrm{C}(=\mathrm{CHPh}) \mathrm{C} \equiv \mathrm{CW}(\mathrm{O})_{2}\left(\mathrm{C}_{5} \mathrm{Me}_{5}\right)\right)(\mathbf{1})$, in which the organic ligand $\mathrm{C} \equiv \mathrm{CC}=\mathrm{CHPh}$ is formed by facile hydride transfer to the diynyl unit, a result consistent with the expected higher activity of $\mathrm{Os}_{3}(u-\mathrm{H})_{2}(\mathrm{CO})_{10} .{ }^{6}$ M oreover, $\mathrm{X}$-ray diffraction analyses of two single crystals of $\mathbf{1}$ provide not only unambiguous structural identification of the linear $\mu-\eta^{3}-\mathrm{C} \equiv \mathrm{CC}=\mathrm{CHPh}$ ligand but also a unique case for hydride dislocation on the triosmium framework by crystal polymorphism.

\section{Experimental Section}

General Information and Materials. Infrared spectra were recorded on a Perkin-Elmer 2000 FT-IR spectrometer. ${ }^{1} \mathrm{H}$ and ${ }^{13} \mathrm{C}$ NMR spectra were recorded on a Bruker AM-400

(4) (a) Lang, H. Angew. Chem., Int. Ed. Engl. 1994, 33, 547. (b) Lagow, R. J .; Kampa, J . J .; Wei, H.-C.; Battle, S. L.; Genge, J . W.; Laude, D. A.; Harper, C.j .; Bau, R.; Stevens, R. C.; Haw, J . F.; Munson, E. Science 1995, 267, 362. (c) Bartik, T.; Bartik, B.; Brady, M. Dembinski, R.; Galdysz, J. A. Angew. Chem., Int. Ed. Engl. 1996, 35, 414. (d) Chi, Y.; Carty, A. J .; Blenkiron, P.; Delgado, E.; Enright, G. D.; Wang, W.; Peng, S.-M.; Lee, G.-H. Organometallics 1996, 15, 5269. (e) Bartik, B.; Dembinski, R.; Bartik, T.; Arif, A. M.; Gladysz, J. A. New J . Chem. 1997, 21, 739.

(5) (a) Brady, M.; Weng, W.; Gladysz, J . A. J . Chem. Soc., Chem. Commun. 1994, 2655. (b) Bruce, M. I.; Skelton, B. W.; White, A. H.; Zaitseva, N. N. J . Chem. Soc., Dalton Trans. 1996, 3151. (c) Bruce, M. I.; Ke, M.; Low, P. J. Chem. Commun. 1996, 2405. (d) Gevert, O.; Wolf, J.; Werner, H. Organometallics 1996, 15, 2806. (e) Bruce, M. I.; Ke, M.; Low, P. J .; Skelton, B. W.; White, A. H. Organometallics 1998, 17, 3539.

(6) (a) Shapley, J . R.; Park, J .-T.; Churchill, M. R.; Ziller, J . W.; Beanan, L. R.J . Am. Chem. Soc. 1984, 106, 1144. (b) Chi, Y.; Shapley, J R.; Churchill, M. R.; Li, Y. J . Inorg. Chem. 1986, 25, 4165. (c) Green M.; Orpen, A. G.; Schaverien, C. J .J . Chem. Soc., Dalton Trans. 1989, 1333. (d) Koike, M.; Hamilton, D. H.; Wilson, S. R.; Shapley, J. R. Organometallics 1996, 15, 4930. 
(400.13 M Hz) or a Bruker AMX-300 (300.6 M Hz) instrument. Mass spectra were measured on a J EOL-HX110 instrument operating in the fast atom bombardment mode (FAB). All reactions were performed under a nitrogen atmosphere using solvents dried with an appropriate reagent. Products were separated on commercially available preparative thin-layer chromatographic plates (Kiesel gel $60 \mathrm{~F}_{254}$, E. Merck). Elemental analyses were performed at the NSC Regional Instrumentation Center at National Cheng Kung University, Tainan, Taiwan.

Reaction of $\mathrm{Os}_{3}(u-\mathrm{H})_{2}(\mathrm{CO})_{10}$ with $\left(\mathrm{C}_{5} \mathrm{Me}_{5}\right) \mathrm{W}(\mathrm{O})_{2}(\mathrm{C} \equiv \mathrm{CC} \equiv$ CPh). In a $100 \mathrm{~mL}$ reaction flask, a $\mathrm{CH}_{2} \mathrm{Cl}_{2}$ solution $(60 \mathrm{~mL})$ of $\mathrm{Os}_{3}(u-\mathrm{H})_{2}(\mathrm{CO})_{10}(180 \mathrm{mg}, 0.21 \mathrm{mmol})$ and the diynyl complex $\left(\mathrm{C}_{5} \mathrm{Me}_{5}\right) \mathrm{W}(\mathrm{O})_{2}(\mathrm{C} \equiv \mathrm{CC} \equiv \mathrm{CPh})(100 \mathrm{mg}, 0.21 \mathrm{mmol})$ was heated at reflux for $3 \mathrm{~h}$, during which period the solution changed from red-purple to red-orange. After removal of solvent under vacuum, the oily residue was dissolved in a minimum amount of $\mathrm{CH}_{2} \mathrm{Cl}_{2}$ and this solution subjected to separation by thinlayer chromatography. Development with a mixture of ethyl acetate, $\mathrm{CH}_{2} \mathrm{Cl}_{2}$, and hexane (3:1:12) produced orange and dark red bands, which were extracted from silica gel with $\mathrm{CH}_{2} \mathrm{Cl}_{2}$, affording yellow-orange $\mathrm{Os}_{3}(\mathrm{CO})_{10}\left(u-\sigma: \eta^{2}-\mathrm{C} \equiv \mathrm{CCHCHPh}\right)(u-\mathrm{H})$ (2; $40.7 \mathrm{mg}, 0.042 \mathrm{mmol}, 20 \%)$ and red $\mathrm{Os}_{3}(\mathrm{CO})_{10}(\mu-\mathrm{H})\left(u-\eta^{3}-\right.$ $\left.\mathrm{C}(=\mathrm{CHPh}) \mathrm{C} \equiv \mathrm{CW}(\mathrm{O})_{2}\left(\mathrm{C}_{5} \mathrm{Me}_{5}\right)\right)(\mathbf{1} ; 110 \mathrm{mg}, 0.083 \mathrm{mmol}, 40 \%)$. Single crystals of $\mathbf{1}$, suitable for $\mathrm{X}$-ray diffraction, were obtained from a mixture of $\mathrm{CH}_{2} \mathrm{Cl}_{2}$ and heptane or from a solution of THF and methanol at $-20^{\circ} \mathrm{C}$, respectively.

Spectral data of $\mathbf{1}$ are as follows. MS (FAB, $\left.{ }^{192} \mathrm{Os},{ }^{184 \mathrm{~W}}\right)$ : $\mathrm{m} / \mathrm{z}$ $1334\left(\mathrm{M}^{+}\right)$. IR $\left(\mathrm{C}_{6} \mathrm{H}_{12}\right): v(\mathrm{CO}) 2123(\mathrm{vw}), 2104(\mathrm{w}), 2068$ (vs), 2054 (vs), 2041 (w), 2034 (w), 2021 (vs), 2004 (m), 1997 (m), 1989 (w), 1986 (w, sh), 1975 (vw), 1964 (vw), 1922 (vw, br) $\mathrm{cm}^{-1}$. ${ }^{1} \mathrm{H}$ NMR $\left(400 \mathrm{MHz}, \mathrm{CD}_{2} \mathrm{Cl}_{2}, 240 \mathrm{~K}\right.$ ): $\delta 7.27-7.16$ (broad, $\left.\mathrm{C}_{6} \mathrm{H}_{5} \& \mathrm{CH}\right), 6.89(\mathrm{~s}, \mathrm{CH}, 0.54 \mathrm{H}), 2.10\left(\mathrm{~s}, \mathrm{C}_{5} \mathrm{Me}_{5}, 0.14 \mathrm{H}\right), 2.03$ $\left(\mathrm{s}, \mathrm{C}_{5} \mathrm{Me}_{5}, 0.32 \mathrm{H}\right), 1.92\left(\mathrm{~s}, \mathrm{C}_{5} \mathrm{Me}_{5}, 0.54 \mathrm{H}\right),-16.91(\mathrm{~s}, \mu-\mathrm{H}, 0.54$ $\mathrm{H}),-17.24(\mathrm{~s}, \mu-\mathrm{H}, 0.14 \mathrm{H})$. Anal. Calcd for $\mathrm{C}_{30} \mathrm{H}_{22} \mathrm{O}_{12} \mathrm{Os}_{3} \mathrm{~W}$ : C, $27.11 ; \mathrm{H}, 1.67$. Found: $\mathrm{C}, 27.50 ; \mathrm{H}, 1.78$.

Spectral data of $\mathbf{2}$ are as follows. MS (FAB, 192Os): $\mathrm{m} / \mathrm{z} 984$ $\left(\mathrm{M}^{+}\right)$. IR ( $\left.\mathrm{C}_{6} \mathrm{H}_{12}\right): v(\mathrm{CO}) 2109$ (w), 2070 (vs), 2061 (s), 2024 (vs), 2005 (s), 1990 (w), 1984 (m) cm ${ }^{-1}$. ${ }^{1} \mathrm{H}$ NMR (400 MHz, CD ${ }^{-2}$ $\left.\mathrm{Cl}_{2}, 220 \mathrm{~K}\right): \delta 7.71\left(\mathrm{~d}, \mathrm{~J}\right.$ нн $\left.=7.2 \mathrm{~Hz}, \mathrm{C}_{6} \mathrm{H}_{5}, 2 \mathrm{H}\right), 7.35-7.23$ $\left(\mathrm{m}, \mathrm{C}_{6} \mathrm{H}_{5}, 3 \mathrm{H}\right), 6.67\left(\mathrm{~d}, \mathrm{~J} \mathrm{HH}_{\mathrm{H}}=12.2 \mathrm{~Hz}, \mathrm{CH}\right), 5.94(\mathrm{~d}, \mathrm{~J} \mathrm{HH}=$ $12.2 \mathrm{~Hz}, \mathrm{CH}),-16.51(\mathrm{~s}, \mu-\mathrm{H}) .{ }^{13} \mathrm{C}$ NMR $\left(100.6 \mathrm{MHz}, \mathrm{CD}_{2} \mathrm{Cl}_{2}\right.$, $223 \mathrm{~K}$ ): CO, $\delta 182.6,182.3,178.4(2 \mathrm{C}), 175.3(2 \mathrm{C}), 171.4(2$ C), $170.0(2 \mathrm{C}) ; \delta 142.4\left(\mathrm{C}_{\delta} \mathrm{H}\right), 135.2\left(\mathrm{i}-\mathrm{C}_{6} \mathrm{H}_{5}\right), 129.6\left(\mathrm{p}-\mathrm{C}_{6} \mathrm{H}_{5}\right)$, $129.0\left(\mathrm{~m}^{-\mathrm{C}_{6}} \mathrm{H}_{5}, 2 \mathrm{C}\right), 128.5\left(\mathrm{o}-\mathrm{C}_{6} \mathrm{H}_{5}, 2 \mathrm{C}\right), 106.8\left(\mathrm{C}_{\gamma} \mathrm{H}\right), 94.1\left(\mathrm{C}_{\beta}\right)$, $79.4\left(\mathrm{C}_{\alpha}\right)$.

Thermolysis of 1. A $\mathrm{CH}_{2} \mathrm{Cl}_{2}$ solution $(40 \mathrm{~mL})$ of $\mathrm{Os}_{3}(\mathrm{CO})_{10^{-}}$ $(\mu-\mathrm{H})\left(\mu-\eta^{3}-\mathrm{C}(=\mathrm{CHPh}) \mathrm{C} \equiv \mathrm{CW}(\mathrm{O})_{2}\left(\mathrm{C}_{5} \mathrm{Me}_{5}\right)\right) \quad(\mathbf{1} ; 120 \mathrm{mg}, 0.090$ $\mathrm{mmol}$ ) was heated at reflux for $40 \mathrm{~h}$. After removal of the solvent in vacuo, the residue was dissolved in $\mathrm{CH}_{2} \mathrm{Cl}_{2}$ and subjected to chromatography. Development with a similar mixture of ethyl acetate, $\mathrm{CH}_{2} \mathrm{Cl}_{2}$, and hexane produced two bands, which were extracted from silica gel to afford yelloworange $\mathrm{Os}_{3}(\mathrm{CO})_{10}\left(\mu-\sigma: \eta^{2}-\mathrm{C} \equiv \mathrm{CCHCHPh}\right)(\mu-\mathrm{H})(2 ; 48 \mathrm{mg}, 0.049$ $\mathrm{mmol}, 54 \%)$ and orange-red $\left(\mathrm{C}_{5} \mathrm{Me}_{5}\right) \mathrm{W}(\mu-\mathrm{O})_{2} \mathrm{Os}_{3}(\mathrm{CO})_{9}\left(\mu-\sigma: \eta^{2}-\right.$ $\mathrm{C} \equiv \mathrm{CCHCHPh})(3 ; 28.5 \mathrm{mg}, 0.022 \mathrm{mmol}, 25 \%)$.

Spectral data of $\mathbf{3}$ are as follows. MS (FAB, $\left.{ }^{192} \mathrm{Os},{ }^{184} \mathrm{~W}\right): \mathrm{m} / \mathrm{z}$ $1306\left(\mathrm{M}^{+}\right)$. IR ( $\left.\mathrm{C}_{6} \mathrm{H}_{12}\right): v(\mathrm{CO}) 2088$ (w), 2069 (vs), 2026 (vs), 2001 (s), 1989 (w), 1973 (vw, br), 1955 (w), 1937 (w) cm ${ }^{-1} .{ }^{1} \mathrm{H}$ NMR $\left(400 \mathrm{MHz} \mathrm{CDCl}_{3}, 230 \mathrm{~K}\right): \delta 7.48\left(\mathrm{~d}, \mathrm{~J} \mathrm{HH}=7.4 \mathrm{~Hz}_{\mathrm{H}} \mathrm{C}_{6} \mathrm{H}_{5}\right)$, 7.40-7.24 (m, $\left.\mathrm{C}_{6} \mathrm{H}_{5}\right), 6.47\left(\mathrm{~d}, \mathrm{~J} \mathrm{HH}_{\mathrm{HH}}=11.9 \mathrm{~Hz}, \mathrm{CH}\right), 2.08\left(\mathrm{~s}, \mathrm{C}_{5}\right.$ $\left.\mathrm{Me}_{5}\right) .{ }^{13} \mathrm{C}$ NMR $\left(100.6 \mathrm{MHz} \mathrm{CDCl}_{3}, 230 \mathrm{~K}\right): \delta 187.2$ (1 CO), 185.4 (2 CO), 177.6 (2 CO), 172.4 (2 CO), 168.9 (2 CO), 138.6 $\left(\mathrm{C}_{\delta} \mathrm{H}\right), 134.8\left(\mathrm{p}-\mathrm{C}_{6} \mathrm{H}_{5}\right), 128.7\left(\mathrm{~m}-\mathrm{C}_{6} \mathrm{H}_{5}\right), 128.1\left(\mathrm{o}-\mathrm{C}_{6} \mathrm{H}_{5}\right), 126.5$ $\left(\mathrm{i}-\mathrm{C}_{6} \mathrm{H}_{5}\right), 115.4\left(\mathrm{C}_{5} \mathrm{Me}_{5}\right), 110.1\left(\mathrm{C}_{\gamma} \mathrm{H}\right), 95.3\left(\mathrm{C}_{\beta}\right), 65.0\left(\mathrm{C}_{\alpha}\right), 12.3$ $\left(\mathrm{C}_{5} \mathrm{Me}_{5}\right.$ ). Anal. Calcd for $\mathrm{C}_{29} \mathrm{H}_{22} \mathrm{O}_{11} \mathrm{Os}_{3} \mathrm{~W}$ : C, 26.77; $\mathrm{H}, 1.70$. Found: C, 26.94; H, 1.75 .

X-ray Crystallography. The X-ray diffraction measurements were made with a Nonius CAD-4 or a Siemens Smart CCD diffractometer at room temperature. For complex $\mathbf{1 a}$, lattice parameters were determined from 25 randomly selected
Table 1. X-ray Structural Data of Complexes 1a and $1 b^{a}$

\begin{tabular}{|c|c|c|}
\hline & 1a & 1b \\
\hline $\begin{array}{l}\text { formula } \\
\text { mol wt }\end{array}$ & $\begin{array}{l}\mathrm{C}_{30} \mathrm{H}_{22} \mathrm{O}_{12} \mathrm{O}_{3} \mathrm{~W} \\
1328.95\end{array}$ & $\begin{array}{l}\mathrm{C}_{30} \mathrm{H}_{22} \mathrm{O}_{12} \mathrm{O}_{3} \mathrm{~W} \\
1328.95\end{array}$ \\
\hline diffractometer & Nonius CAD-4 & Siemens Smart CCD \\
\hline cryst syst & monoclinic & monodinic \\
\hline $\begin{array}{l}\text { space group } \\
\text { a }(\AA)\end{array}$ & $\begin{array}{l}C 2 / C \\
34.79(5)\end{array}$ & $\begin{array}{l}\text { Cc } \\
21.6673(3)\end{array}$ \\
\hline $\mathrm{b}(\AA)$ & $12.973(4)$ & $16.4637(2)$ \\
\hline$c(\AA)$ & $14.917(4)$ & $14.5454(1)$ \\
\hline$\beta\left(^{\circ}\right)$ & $98.88(3)$ & $131.467(1)$ \\
\hline$V\left(\AA^{3}\right)$ & $6653(3)$ & $3888.08(8)$ \\
\hline Z & 8 & 4 \\
\hline$D_{c}\left(\mathrm{~g} / \mathrm{cm}^{3}\right)$ & 2.654 & 2.270 \\
\hline$F(000)$ & 4800 & 2400 \\
\hline $2 \theta(\max )(\mathrm{deg})$ & 50.0 & 55.0 \\
\hline hkl ranges & $\begin{array}{l}-41 \text { to }+40,0-15 \\
0-17\end{array}$ & $\begin{array}{l}-28 \text { to }+24,-21 \text { to }+21 \\
-13 \text { to }+18\end{array}$ \\
\hline crystal size (mm) & $0.30 \times 0.25 \times 0.25$ & $0.45 \times 0.17 \times 0.16$ \\
\hline$\mu(\operatorname{MoK} \alpha)\left(\mathrm{cm}^{-1}\right)$ & 150.08 & 127.72 \\
\hline $\begin{array}{l}\text { transmissn: max, } \\
\text { min }\end{array}$ & $0.737,0.693$ & $0.746,0.362$ \\
\hline $\begin{array}{l}\text { no. of data in } \\
\text { refinement }\end{array}$ & 3908 with $I \geq 2 \sigma(I)$ & 7055 \\
\hline no. of params & 419 & 416 \\
\hline $\max \mu / \sigma$ ratio & 0.001 & 0.02 \\
\hline $\begin{array}{l}\mathrm{R}_{\mathrm{F}} ; \mathrm{R}_{\mathrm{W}} \text { or } \\
\quad \mathrm{RF} ; \mathrm{R}_{\mathrm{WF}^{2}}\end{array}$ & $0.037 ; 0.033$ & $0.036 ; 0.077$ \\
\hline GOF & 1.23 & 1.05 \\
\hline $\begin{array}{l}\text { D-map, max/min } \\
\left(\mathrm{e} / \AA^{-3}\right)\end{array}$ & $1.14 /-1.81$ & $1.57 /-0.77$ \\
\hline
\end{tabular}

a Features common to all determinations: $\lambda(\mathrm{M} \circ \mathrm{K} \alpha)=0.7107$ $\AA$; function minimized $\sum\left(\mathrm{w}\left|\mathrm{F}_{\mathrm{o}}-\mathrm{F}_{\mathrm{c}}\right|^{2}\right)$; weighting scheme $\mathrm{w}^{-1}=$ $\sigma^{2}\left(\mathrm{~F}_{0}\right)+|\mathrm{g}| \mathrm{F}_{0}{ }^{2} ; \mathrm{GOF}=\left[\Sigma \mathrm{w}\left|\mathrm{F}_{\mathrm{o}}-\mathrm{F}_{\mathrm{c}}\right|^{2} /\left(\mathrm{N}_{\mathrm{o}}-\mathrm{N}_{\mathrm{v}}\right)\right]^{1 / 2}\left(\mathrm{~N}_{\mathrm{o}}=\right.$ number of observations; $\mathrm{N}_{\mathrm{v}}=$ number of variables).

high-angle reflections. Three standard reflections were monitored every $3600 \mathrm{~s}$. No significant change of intensities $(\leq 2 \%)$ was observed during the course of all data collection. Intensities of diffraction signals were corrected for Lorentz, polarization, and absorption effects ( $\psi$ scans). The structure was solved with the NRCC-SDP-VAX package. All non-hydrogen atoms had anisotropic temperature factors; hydrogen atoms of organic substituents were placed at calculated positions with $U_{H}$ $=\mathrm{U}_{\mathrm{C}}+0.1$.

Single-crystal X-ray diffraction data of $\mathbf{1 b}$ were measured on a Siemens SMART CCD diffractometer. Reflections were collected using three different $\varphi$ setting angles; each setting was scanned by $0.3 \omega$ between frames. Each frame was exposed for $5 \mathrm{~s}$. The detector was located $4.0 \mathrm{~cm}$ away from the crystal. Crystal decay was monitored by repeating the initial 50 frames at the end of data collection and analyzing the duplicate reflections, and no decay was observed. An empirical absorption correction using SADABS was applied. The structure was solved by the direct method. Hydrogen atoms were fixed at calculated positions and refined using a riding model. Anisotropic displ acement parameters were used for all non-H atoms, while the given isotropic displacement parameters were used for $\mathrm{H}$ atoms (1.2 and 1.5 times the equivalent isotropic displacement parameter of the atom to which they are respectively attached for methylene $\mathrm{H}$ atoms and methyl $\mathrm{H}$ atoms). Data collection was carried out by using the SMART program. Cell refinement and data reduction were performed by using the SAINT program. Structure analysis was carried out by using the SHELXTL/PC program.

Crystallographic refinement parameters of $\mathbf{l a}$ and $\mathbf{1 b}$ are summarized in Table 1; selected bond distances and angles are presented in Tables 2 and 3, respectively.

\section{Results and Discussion}

Formation and Characterization of $\mathbf{1}$. The reaction of the hydridoosmium complex $\mathrm{Os}_{3}(\mu-\mathrm{H})_{2}(\mathrm{CO})_{10}$ with 
Table 2. Selected Bond Distances $(\AA)$ and Angles (deg) of la (Esd's in Parentheses)

\begin{tabular}{lclc}
\hline Os(1)-Os(2) & $2.959(1)$ & Os(1)-Os(3) & $2.915(1)$ \\
Os(2)-Os(3) & $2.877(1)$ & Os(1)-C(11) & $2.42(1)$ \\
Os(1)-C(12) & $2.53(1)$ & Os(2)-C(13) & $2.15(1)$ \\
W-C(11) & $2.10(1)$ & $\mathrm{W}-\mathrm{O}(11)$ & $1.71(1)$ \\
$\mathrm{W}-\mathrm{O}(12)$ & $1.71(1)$ & $\mathrm{C}(11)-\mathrm{C}(12)$ & $1.23(2)$ \\
$\mathrm{C}(12)-\mathrm{C}(13)$ & $1.43(2)$ & $\mathrm{C}(13)-\mathrm{C}(14)$ & $1.32(2)$ \\
$\mathrm{Os}(1)-\mathrm{H}$ & $1.81(1)$ & $\mathrm{Os}(2)-\mathrm{H}$ & $1.72(1)$ \\
$\angle \mathrm{Os}(1)-\mathrm{Os}(2)-\mathrm{Os}(3)$ & $59.91(3)$ & $\angle \mathrm{Os}(1)-\mathrm{Os}(3)-\mathrm{Os}(2)$ & $61.45(3)$ \\
$\angle \mathrm{Os}(2)-\mathrm{Os}(1)-\mathrm{Os}(3)$ & $58.64(3)$ & $\angle \mathrm{W}-\mathrm{C}(11)-\mathrm{C}(12)$ & $152(1)$ \\
$\angle \mathrm{C}(11)-\mathrm{C}(12)-\mathrm{C}(13)$ & $173(1)$ & $\angle \mathrm{C}(12)-\mathrm{C}(13)-\mathrm{C}(14)$ & $123(1)$ \\
$\angle \mathrm{C}(11)-\mathrm{W}-\mathrm{O}(11)$ & $103.9(5)$ & $\angle \mathrm{C}(11)-\mathrm{W}-\mathrm{O}(12)$ & $100.6(5)$ \\
$\angle \mathrm{O}(11)-\mathrm{W}-\mathrm{O}(12)$ & $108.7(5)$ & &
\end{tabular}

Table 3. Selected Bond Distances $(\AA)$ and Angles (deg) of $\mathbf{1 b}$ (Esd's in Parentheses)

\begin{tabular}{llll}
\hline Os(1)-Os(2) & $2.8451(6)$ & $\mathrm{Os}(1)-\mathrm{Os}(3)$ & $3.0741(6)$ \\
$\mathrm{Os}(2)-\mathrm{Os}(3)$ & $2.8996(7)$ & $\mathrm{Os}(1)-\mathrm{C}(11)$ & $2.30(1)$ \\
$\mathrm{Os}(1)-\mathrm{C}(12)$ & $2.46(1)$ & $\mathrm{Os}(2)-\mathrm{C}(13)$ & $2.13(1)$ \\
$\mathrm{W}-\mathrm{C}(11)$ & $2.15(1)$ & $\mathrm{W}-\mathrm{O}(11)$ & $1.71(1)$ \\
$\mathrm{W}-\mathrm{O}(12)$ & $1.72(1)$ & $\mathrm{C}(11)-\mathrm{C}(12)$ & $1.24(2)$ \\
$\mathrm{C}(12)-\mathrm{C}(13)$ & $1.35(2)$ & $\mathrm{C}(13)-\mathrm{C}(14)$ & $1.36(2)$ \\
\multicolumn{5}{l}{$\mathrm{Os}(1)-\mathrm{Os}(2)-\mathrm{Os}(3)$} & $64.70(2)$ & $\angle \mathrm{Os}(1)-\mathrm{Os}(3)-\mathrm{Os}(2)$ & $56.80(2)$ \\
$\angle \mathrm{Os}(2)-\mathrm{Os}(1)-\mathrm{Os}(3)$ & $58.51(2)$ & $\angle \mathrm{W}-\mathrm{C}(11)-\mathrm{C}(12)$ & $147(1)$ \\
$\angle \mathrm{C}(11)-\mathrm{C}(12)-\mathrm{C}(13)$ & $177(1)$ & $\angle \mathrm{C}(12)-\mathrm{C}(13)-\mathrm{C}(14)$ & $124(1)$ \\
$\angle \mathrm{C}(11)-\mathrm{W}-\mathrm{O}(11)$ & $101.7(5)$ & $\angle \mathrm{C}(11)-\mathrm{W}-\mathrm{O}(12)$ & $102.8(4)$ \\
$\angle \mathrm{O}(11)-\mathrm{W}-\mathrm{O}(12)$ & $106.4(5)$ & &
\end{tabular}

the tungsten acetylide complex $\left(\mathrm{C}_{5} \mathrm{Me}_{5}\right) \mathrm{W}(\mathrm{O})_{2}(\mathrm{C} \equiv \mathrm{CC} \equiv$ $\mathrm{CPh}$ ) in $\mathrm{CH}_{2} \mathrm{Cl}_{2}$ at reflux gives the heterometallic compound $\mathrm{Os}_{3}(\mathrm{CO})_{10}(u-\mathrm{H})\left(u-\eta^{3}-\mathrm{C}(=\mathrm{CHPh}) \mathrm{C} \equiv \mathrm{CW}(\mathrm{O})_{2^{-}}\right.$ $\left.\left(\mathrm{C}_{5} \mathrm{Me}_{5}\right)\right)(\mathbf{1})$ as a red solid. This compounds is relatively unstable in solution upon exposure to air; therefore, recrystallization is carried out in a mixture of $\mathrm{CH}_{2} \mathrm{Cl}_{2}$ and heptane at $-20^{\circ} \mathrm{C}$. FAB MS analysis of 1 shows a parent ion $\mathrm{M}^{+}$at $\mathrm{m} / \mathrm{z} 1334$ that is consistent with formation of a molecular formula corresponding to a 1:1 combination of starting materials. The IR spectrum in cycl ohexane solution exhibits nearly 20 overlapping CO stretching bands in the range $2123-1922 \mathrm{~cm}^{-1}$, indicative of at least two structural isomers. This behavior is confirmed by subsequent ${ }^{1} \mathrm{H}$ NMR analysis. I $\mathrm{n}$ addition to a broad and complicated signal at $\delta$ 7.27-7.16 assigned to aromatic and ol efinic hydrogens, we observed three distinctive hydride signals at $\delta-16.91$, -17.24 , and -17.73 with the relative intensity ratio 3.9 : 2.3:1, demonstrating the coexistence of three isomers (Scheme 1). To establish their mol ecular structures and the interrelationships, we carried out the X-ray diffraction study of a single crystal obtained from $\mathrm{CH}_{2} \mathrm{Cl}_{2} /$ heptane solution.

The molecular structure of this heterometallic compound labeled 1a is depicted in Figure 1; selected bond lengths and angles appear in Table 2 . The structure contains a triangular osmium framework with 10 terminal $\mathrm{CO}$ ligands. The arrangement of $\mathrm{CO}$ ligands on this osmium triangle is similar to those of the clusters $\mathrm{Os}_{3}(\mu-\mathrm{X})(\mu-\mathrm{H})(\mathrm{CO})_{10},{ }^{7}$ in which one Os-Os edge is bridged by ligand $X(X=$ three-electron donor $)$ and a hydride ligand located bel ow the osmium triangle. One hydride ligand bridging the Os(1)-Os(2) edge is positively defined by difference Fourier synthesis. The second hydride migrates to the terminal carbon atom

(7) (a) Deeming, A. J . Adv. Organomet. Chem. 1986, 26, 1. (b) Smith, A. K. In Comprehensive Organometallic Chemistry II; Abel, E. W., Stone, F. G. A., Wilkinson, G., Eds.; Pergamon: Oxford, U.K., 1982; Vol. 7, Chapter 13.

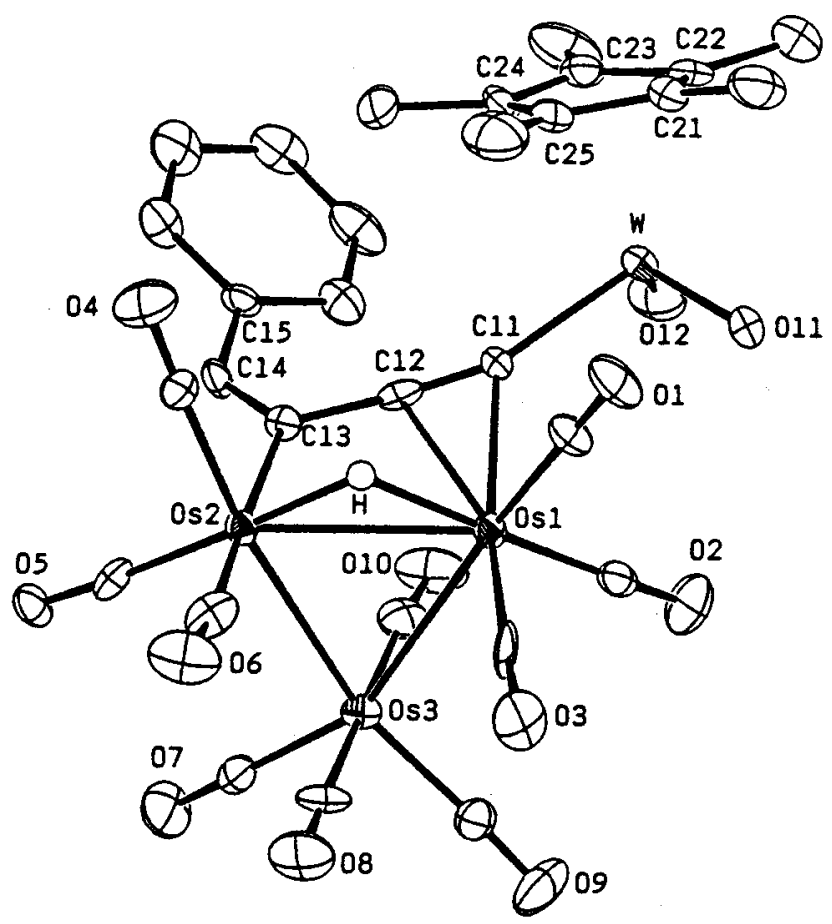

Figure 1. Molecular structure and atomic labeling scheme of the complex $\mathrm{Os}_{3}(\mathrm{CO})_{10}(\mu-\mathrm{H})\left(\mu-\eta^{3}-\mathrm{C}(=\mathrm{CHPh}) \mathrm{C} \equiv \mathrm{CW}(\mathrm{O})_{2^{-}}\right.$ $\left(\mathrm{C}_{5} \mathrm{Me}_{5}\right)$ ) (1a) with thermal ellipsoids shown at the $30 \%$ probability level.

\section{Scheme 1}
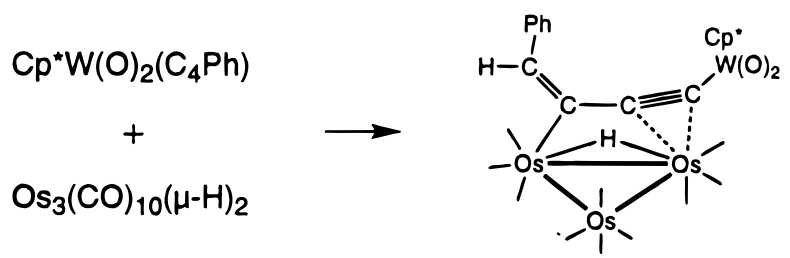

(1a)

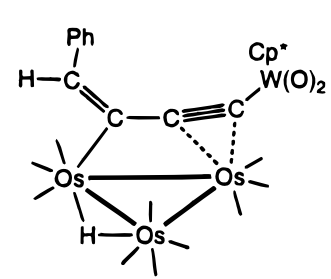

(1c)

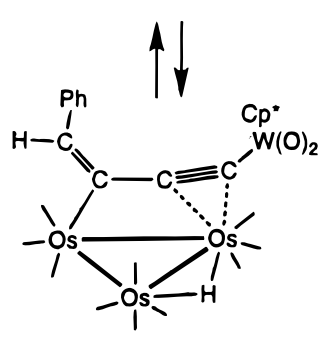

(1b)
$\mathrm{C}(14)$ of the incoming acetylide complex $\left(\mathrm{C}_{5} \mathrm{Me}_{5}\right) \mathrm{W}(\mathrm{O})_{2^{-}}$ $(\mathrm{C} \equiv \mathrm{CC} \equiv \mathrm{CPh})$, giving a novel $\mathrm{C} \equiv \mathrm{CC}=\mathrm{CHPh}$ fragment which is confirmed by observation of a $\mathrm{C}-\mathrm{C}$ double bond with distance 1.32(2) $\AA$ between $C(13)$ and C(14) atoms. The resulting $\mathrm{C}_{4}$ hydrocarbon fragment is coordinated to the triosmium framework in two axial sites; one is filled by carbon atom $\mathrm{C}(13)$, forming a regular $\sigma$-bond with distance 2.15(1) $\AA$, whereas the second has a $\pi$-interaction from alkyne fragment $\mathrm{C}(11)-\mathrm{C}(12)$ with $\mathrm{Os}(1)-\mathrm{C}(11)=2.42(1) \AA$ and $\mathrm{Os}(1)-\mathrm{C}(12)=2.53(1) \AA$. The resulting $C(13)-C(12)-C(11)$ unit is linear with bond angle $173(1)^{\circ}$ and is nearly parallel to the Os(1)Os(1) edge. This novel $\mu-\eta^{3}$-bonding mode is in contrast to that of a related hydrocarbyl ligand in the allyl 


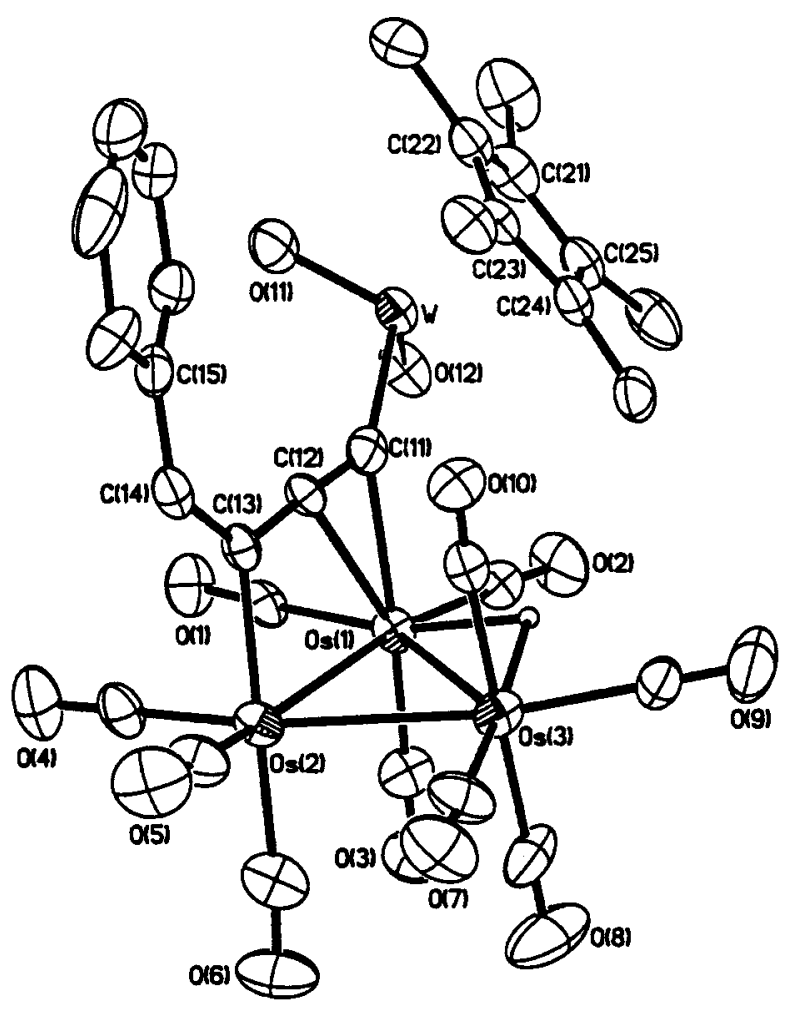

Figure 2. Molecular structure and atomic labeling scheme of the complex $\mathrm{Os}_{3}(\mathrm{CO})_{10}(u-\mathrm{H})\left(u-\eta^{3}-\mathrm{C}(=\mathrm{CHPh}) \mathrm{C} \equiv \mathrm{CW}(\mathrm{O})_{2^{-}}\right.$ $\left.\left(\mathrm{C}_{5} \mathrm{Me}_{5}\right)\right)(\mathbf{1 b})$ with thermal ellipsoids shown at the $30 \%$ probability level.

complex $\mathrm{Os}_{3}(\mathrm{CO})_{10}\left(\mu-\mathrm{AuPEt}_{3}\right)\left(\mu-\eta^{3}-\mathrm{C}_{3} \mathrm{H}_{5}\right),{ }^{8}$ in which the $\mathrm{AuPEt}_{3}$ ligand is isolobal with a hydride, whereas the allyl ligand, adapting a $\mu_{2}-\eta^{3}$-mode and serving as a three-electron donor, is found to coordinate to equatorial sites on the triosmium triangle, not the axial sites. Another notable feature is the pendant $\left(\mathrm{C}_{5} \mathrm{Me}_{5}\right) \mathrm{W}(\mathrm{O})_{2}$ fragment that resides above equatorial $\mathrm{CO}$ ligands on the atom Os(2). The lengths of bonds between the $\mathrm{W}$ atom and terminal oxo ligands $(\mathrm{W}-\mathrm{O}(11), \mathrm{W}-\mathrm{O}(12)=$ $1.71(1) \AA$ ) are similar to the average $\mathrm{W}=\mathrm{O}$ distance observed in the anionic complex $\left[\left(\mathrm{C}_{5} \mathrm{Me}_{5}\right) \mathrm{W}(\mathrm{O})_{3}\right][\mathrm{PPN}]^{9}$ and in the parent dioxo complex $\left(\mathrm{C}_{5} \mathrm{Me}_{5}\right) \mathrm{W}(\mathrm{O})_{2}(\mathrm{C} \equiv$ $\mathrm{CPh}){ }^{10}$

The structure of $\mathbf{l a}$ evidently represents one isomeric structure detected in ${ }^{1} \mathrm{H}$ NMR spectra. The second structure (1) is is established with X-ray diffraction study of another single crystal obtained from a mixed solution of THF and methanol at $-20^{\circ} \mathrm{C}$. Preliminary X-ray analysis indicates that the cell parameters of $\mathbf{1 b}$ are not the same as those of $\mathbf{1 a}$. For example, the unit cell volume of $\mathbf{1 b}$ is substantially greater, indicating a less efficient packing for molecules in the solid state. This observation prompted us to undertake the next singlecrystal X-ray analysis.

As indicated in Figure 2, the structure of $\mathbf{1 b}$ differs little from that of $\mathbf{1 a}$, consisting of three fundamental building blocks: a triangular $\mathrm{Os}_{3}(\mathrm{CO})_{10}$ unit, a bridging

(8) Housecroft, C. E.; J ohnson, B. F. G.; Lewis, J .; Lunniss, J . A.; Owen, S. M.; Raithby, P. R. J . Organomet. Chem. 1991, 409, 271.

(9) (a) Rau, M. S.; Kertz, C. M.; Mercando, L. A.; Geoffroy, G. L.; Rheingold, A. L. J . Am. Chem. Soc. 1991, 113, 7420. (b) Rau, M. S.; Kretz, C. M.; Geoffroy, G. L. Organometallics 1993, 12, 3447.

(10) Shiu, C.-W.; Su, C.-J .; Pin, C.-W.; Chi, Y.; Peng, S.-M.; Lee, G.H. J . Organomet. Chem. 1997, 545-546, 151. hydride, and a coordinated $\left(\mathrm{C}_{5} \mathrm{Me}_{5}\right) \mathrm{W}(\mathrm{O})_{2}(\mathrm{C} \equiv \mathrm{CC}=$ $\mathrm{CHPh}$ ) unit attached to two osmium atoms at adjacent axial sites. However, the $\left(\mathrm{C}_{5} \mathrm{Me}_{5}\right) \mathrm{W}(\mathrm{O})_{2}$ fragment here undergoes a $180^{\circ}$ rotation about the $\mathrm{W}-\mathrm{C}$ bond, placing terminal oxo ligands in positions away from the unique $\mathrm{Os}(\mathrm{CO})_{4}$ fragment. Moreover, a hydride is found to bridge the Os(1)-Os(3) edge (3.0741(6) $\AA$ ), not the Os(1)-Os(2) edge as observed earlier, which is verified by a slight elongation of the Os-Os vector with respect to other Os-Os edges: Os(1)-Os(2) = 2.845(6) $\AA$ and Os$(2)-O s(3)=2.8996(7) \AA$. Thus, the structures of $\mathbf{1 a}$ and 1b are related by hydride migration between two adjacent Os-Os edges. By further extending this de lineation, we assume that the last isomer (1c) would possess a structure with the hydride ligand associated with the third Os-Os edge (Scheme 1). This isomerization is consistent with a well-established tendency of hydride to migrate on a polymetallic cluster framework. ${ }^{11}$

Thermolysis of $\mathbf{1}$. Decarbonylation of $\mathbf{1}$ is achieved on extensive thermolysis in $\mathrm{CH}_{2} \mathrm{Cl}_{2}$ at reflux (40 h). Separation of the reaction mixture by thin-layer chromatography yields two major bands. The first fasteluting band is due to the yellow triosmium compound $\mathrm{Os}_{3}(\mathrm{CO})_{10}\left(\mu-\sigma: \eta^{2}-\mathrm{C} \equiv \mathrm{CCHCHPh}\right)(\mu-\mathrm{H})(2)$, but this com-

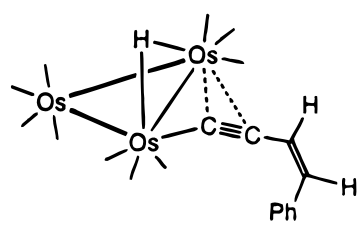

(2)

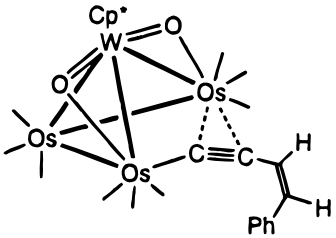

(3) plex is relatively unstable, forming some intractable materials on dissolution in air at room temperature. As such, its recrystallization must be carried out at -20 ${ }^{\circ} \mathrm{C}$ and no attempt was made to obtain microanalysis data because of the poor thermal stability. I n contrast, the second, red-orange band is more stable and consists of the complex $\left(\mathrm{C}_{5} \mathrm{Me}_{5}\right) \mathrm{W}(\mu-\mathrm{O})_{2} \mathrm{Os}_{3}(\mathrm{CO})_{9}\left(u-\sigma: \eta^{2}-\mathrm{C} \equiv\right.$ $\mathrm{CCHCHPh)} \mathrm{(3).} \mathrm{I} \mathrm{ts} \mathrm{formation} \mathrm{is} \mathrm{a} \mathrm{result} \mathrm{of} \mathrm{competitive}$ loss of $\mathrm{CO}$ and coordination of the $\left(\mathrm{C}_{5} \mathrm{Me}_{5}\right) \mathrm{W}(\mathrm{O})_{2}$ unit to the osmium framework, a sequence which is typical for the related oxo carbonyl cluster compounds. ${ }^{12}$

Characterization of $\mathbf{2}$ and $\mathbf{3}$. For complex 2, the $\mathrm{FAB}$ mass spectrum shows parent molecular ions assigned to $\mathrm{C}_{20} \mathrm{H}_{10} \mathrm{H}_{8} \mathrm{Os}_{3}$; the IR spectrum in the $v(\mathrm{CO})$ region closely resembles that of the compound $\mathrm{Os}_{3}-$ $(\mathrm{CO})_{10}(u-\mathrm{H})\left(u-\sigma: \eta^{2}-\mathrm{C} \equiv \mathrm{CPh}\right){ }^{13}$ Furthermore, the ${ }^{13} \mathrm{C}$ NMR spectrum was then recorded at $220 \mathrm{~K}$, giving eight ${ }^{13} \mathrm{C}$ NMR signals in the region $\delta$ 142.4-79.4, attributed to a $\mu-\mathrm{C} \equiv \mathrm{CCH}=\mathrm{CHPh}$ fragment. Six sharp ${ }^{13} \mathrm{C}$ NMR signals at $\delta 182.6,182,178.4,175.3,171.4$, and 170.0 with intensity ratio 1:1:2:2:2:2 are also observed, show-

(11) (a) Band, E.; Muetterties, E. L. Chem. Rev. 1978, 78, 639. (b) Humphries, A. P.; Kaesz, H. D. Prog. Inorg. Chem. 1979, 25, 146. (c) Farrugia, L. J . Adv. Organomet. Chem. 1990, 31, 301.

(12) (a) Blenkiron, P.; Carty, A. J .; Peng, S.-M.; Lee, G.-H.; Su, C.J .; Shiu, C.-W.; Chi, Y. Organometallics 1997, 16, 519. (b) Chao, W.J .; Chi, Y.; Chung, C.; Carty, A. J .; Delgado, E.; Peng, S.-M.; Lee, G.H. J . Organomet. Chem. 1998, 565, 3.

(13) (a) Deeming, A. J .; Hasso, S.; Underhill, M. J . Chem. Soc., Dalton Trans. 1975, 1614. (b) Koridze, A. A.; Kizas, O. A.; Petrovskii, P. V.; Kolobova, N. E.; Struchkov, Yu. T.; Yanovsky, A. I. J . Organomet. Chem. 1988, 338, 81. 
ing the acetylide ligand undergoing a facile $\sigma \rightarrow \pi, \pi \rightarrow$ $\sigma$ rearrangement, which produces a time-averaged plane of mirror symmetry bisecting the entire molecule. The CO chemical shifts observed and the respective dynamic behavior are all consistent with those of the complex $\mathrm{Os}_{3}(\mathrm{CO})_{10}(\mu-\mathrm{H})\left(\mu-\sigma: \eta^{2}-\mathrm{C} \equiv \mathrm{CPh}\right)$. In addition, the ${ }^{1} \mathrm{H}$ NMR spectrum exhibits a signal at $\delta-16.51$, characteristic of hydride bridging a Os-Os bond, a doublet at $\delta 7.71$, and a multiplet centered at $\delta 7.29$ due to the phenyl group. Notably, a pair of doublets at $\delta 6.67$ and 5.94 with the coupling constant ${ }^{3} \mathrm{HH}=12.2 \mathrm{~Hz}$ are observed, which pertain to ol efinic protons that are cisdisposed.

On the other hand, the structure of $\mathbf{3}$ is assigned with reasonable certainty from FAB MS analysis and from the analysis of the IR $v(\mathrm{CO})$ spectrum in the region 2088-1937 $\mathrm{cm}^{-1}$. Agreement between this $v$ (CO) pattern with those observed for the structurally characterized complexes $\mathrm{CpW}(\mu-\mathrm{O})_{2} \mathrm{Os}_{3}(\mathrm{CO})_{9}(\mu-\mathrm{H})^{14}$ and $\left(\mathrm{C}_{5}-\right.$ $\left.\mathrm{Me}_{5}\right) \mathrm{W}(\mu-\mathrm{O})_{2} \mathrm{Os}_{3}(\mathrm{CO})_{9}\left(\mu-\sigma: \eta^{2}-\mathrm{C} \equiv \mathrm{CPh}\right)^{15}$ is excellent. Thus, the cluster core geometry can be definitely assigned to have the symmetrical butterfly skeletal arrangement of a $\left(\mathrm{C}_{5} \mathrm{Me}_{5}\right) \mathrm{W}(\mu-\mathrm{O})_{2} \mathrm{Os}_{3}(\mathrm{CO})_{9}$ unit. In agreement with this assignment, the ${ }^{13} \mathrm{C} N M R$ spectrum shows a time-averaged, five-line pattern for Os-CO signals at $\delta 187.2,185.4,177.6,172.4$, and 168.9 with intensity ratio 1:2:2:2:2. The ${ }^{1} \mathrm{H}$ NMR spectrum exhibits the expected signals for the phenyl group and two doublets at $\delta 6.47$ and 6.14 assigned to the $\mathrm{CH}=\mathrm{CHPh}$ unit. The coupling constant ${ }^{3} \mathrm{H} \mathrm{HH}=11.9 \mathrm{~Hz}$ is essentially identical with that observed in 2, demonstrating the same cis-disposition of the $\mathrm{CH}=\mathrm{CHPh}$ unit.

Summary. Complex $\mathbf{1}$ forms three isomers in solution and maintains a constant ratio of isomers in solvents such as $\mathrm{CD}_{2} \mathrm{Cl}_{2}$ and $\mathrm{d}_{8}-\mathrm{THF}$. The structures of $\mathbf{l a}$ and $\mathbf{1 b}$ represent an unique example of tetrametallic clusters identified by X-ray diffraction to have a hydride located on two distinct positions of the cluster framework. The reason for variation of the solid-state structure is unclear but may be associated with the polarity of solvents used for recrystallization. It is possible that the interaction of solvent molecules with oxo ligands perturbs packing of the $\left(\mathrm{C}_{5} \mathrm{Me}_{5}\right) \mathrm{W}(\mathrm{O})_{2}$ pendant within the molecule, inducing the hydride to move from one

(14) Chi, Y.; Hwang, L.-S.; Lee, G.-H.; Peng, S.-M. J . Chem. Soc., Chem. Commun. 1988, 1456.

(15) (a) Shiu, C.-W.; Chi, Y.; Carty, A. J .; Peng, S.-M.; Lee, G.-H. Organometallics 1997, 16, 5368. (b) Shiu, C.-W.; Chi, Y.; Chung, C.; Peng, S.-M.; Lee, G.-H. Organometallics 1998, 17, 2970.

(16) (a) Draper, S. M.; Housecroft, C. E.; Keep, A. K.; Matthews, D. M.: Song, X.; Rheingold, A. L. J . Organomet. Chem. 1992, 423, 241. (b) Hong, F.; Coffy, T. L.; McCarthy, D. A.; Shore, S. G. Inorg. Chem. 1989, 28, 3284.

(17) (a) Garlaschelli, L.; Martinengo, S.; Bellon, P. L.; Demartin, F.; Manassero, M.; Chiang, M. Y.; Wei, C. Y.; Bau, R. J . Am. Chem. Soc. 1984, 106, 6664. (b) Braga, D.; Grepioni, F.; Dyson, P. J .; J ohnson, B. F. G.; Frediani, P.; Bianchi, M.; Piacenti, F. J . Chem. Soc., Dalton Trans. 1992, 2565.

(18) Pin, C.-W.; Chi, Y.; Chung, C.; Carty, A. J .; Peng, S.-M.; Lee, G.-H. Organometallics 1998, 17, 4161.
Scheme 2

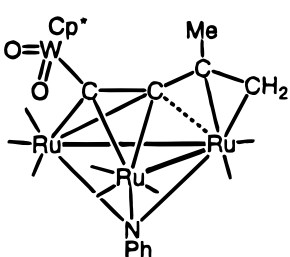

(4)

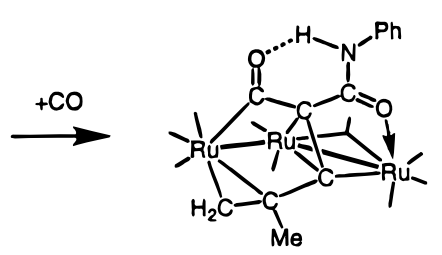

(5)
Os-Os edge to another during crystallization. A crystal polymorphism involving the hydride ligand has been documented for the cluster $\mathrm{Ru}_{6}(\mu-\mathrm{H})\left(\mu_{6}-\mathrm{B}\right)(\mathrm{CO})_{17},{ }^{16}$ in which the isomeric pairs differ in the rotameric conformation of $\mathrm{Ru}(\mathrm{CO})_{3}$ units and in the location of hydride. Other isomerism that is relevant to the present study is also observed in the compounds $\mathrm{Ir}_{6}(\mathrm{CO})_{16}$ and $\mathrm{Ru}_{6^{-}}$ $\left(\mu_{6}-\mathrm{C}\right)(\mathrm{CO})_{17 .}{ }^{17}$ As they possess no bridging hydride ligand, the isomerism arises entirely from the disposition of CO ligands with respect to the central cluster framework.

Furthermore, a mechanism leading to formation of $\mathbf{2}$ and $\mathbf{3}$ can be deduced according to their structures. Complex $\mathbf{3}$ is clearly produced in a sequence involving decarbonylation and migration of hydride to the $\mu-\eta^{3}$ $\mathrm{C} \equiv \mathrm{CC}=\mathrm{CHPh}$ ligand. Formation of this cis- $\mathrm{C} \equiv \mathrm{CCH}=$ $\mathrm{CHPh}$ ligand favors a pathway involving direct transfer of hydride to the $\mathrm{C} \equiv \mathrm{CC}=\mathrm{CHPh}$ ligand of $\mathbf{1}$; otherwise, production of a mixture of trans and cis isomers is envisaged. In contrast, the formation of $\mathbf{2}$ seems to involve removal of the $\left(\mathrm{C}_{5} \mathrm{Me}_{5}\right) \mathrm{W}(\mathrm{O})_{2}$ unit and concomitant addition of a hydrogen atom. This novel process is reminiscent of conversion from the heterometallic oxo carbonyl complex $\mathrm{Ru}_{3}(\mathrm{CO})_{8}\left(\mu_{3}-\mathrm{NPh}\right)\left(\mu-\eta^{4}-\mathrm{CH}_{2} \mathrm{CMeC} \equiv\right.$ $\left.\mathrm{CW}(\mathrm{O})_{2}\left(\mathrm{C}_{5} \mathrm{Me}_{5}\right)\right)$ to the triruthenium complex $\mathrm{Ru}_{3}(\mathrm{CO})_{9-}$ $\left[\mathrm{CH}_{2} \mathrm{CMeCC}(\mathrm{CONHPh}) \mathrm{CO}\right]$ (Scheme 2). ${ }^{18}$ To understand how this reaction occurs, imagine that an $\mathrm{H}_{2} \mathrm{O}$ molecule (or an equivalent) is introduced into the reaction system by chance or during workup. I n effect, it reacts with the $\left(\mathrm{C}_{5} \mathrm{Me}_{5}\right) \mathrm{W}(\mathrm{O})_{2}$ fragment, giving off the unstable $\left[\left(\mathrm{C}_{5} \mathrm{Me}_{5}\right) \mathrm{W}(\mathrm{O})_{2} \mathrm{OH}\right]$ and a proton. The coproduct $\left[\left(\mathrm{C}_{5} \mathrm{Me}_{5}\right) \mathrm{W}(\mathrm{O})_{2} \mathrm{OH}\right]$ adsorbs on silica gel, and the proton remains on the cluster framework to afford the isolated homometallic complex $\mathbf{2}$. This postulation has been substantiated by in situ ${ }^{1} \mathrm{H}$ NMR studies, which indicate almost no formation of $\mathbf{2}$ prior to chromatographic separation.

Acknowledgment. We thank the National Sciences Council of Taiwan (NSC Grant No. 87-2113-M 007-047) for support of this work.

Supporting Information Available: Tables of nonessential crystal data, bond lengths, atomic coordinates, and corresponding anisotropic thermal parameters for structures $\mathbf{l a}$ and $\mathbf{1 b}$. This material is available free of charge via the Internet at http://pubs.acs.org.

OM980957Z 